\title{
Effects of Copaiba Oil on Cyclophosphamide- Induced Teratogenesis in Mice
}

\author{
Ana Carolina dos Santos Lourenço' ${ }^{1}$ José Eduardo Baroneza², Solange de Paula Ramos³, \\ Liliane Kelen Miguel', Luiz Carlos Juliani3 ${ }^{3}$, Aline Pic-Taylor ${ }^{5}$, Maria José Sparça Salles ${ }^{4}$ \\ ${ }^{1}$ Departmento de Farmacologia, Centro de Ciências Biológicas, Universidade Federal do Paraná, Curitiba, Brazil \\ ${ }^{2}$ Universidade Positivo, Curitiba, Brazil \\ ${ }^{3}$ Departmento de Histologia, Centro de Ciências Biológicas, Universidade Estadual de Londrina, Londrina, Brazil \\ ${ }^{4}$ Departmento de Biologia Geral, Centro de Ciências Biológicas, Universidade Estadual de Londrina, Londrina, \\ Brazil \\ ${ }^{5}$ Departmento de Genética e Morfologia, Universidade de Brasília, Brasília, Brazil \\ Email: salmjs00@gmail.com
}

Received 27 September 2014; revised 26 October 2014; accepted 9 November 2014

Copyright (C) 2014 by authors and Scientific Research Publishing Inc.

This work is licensed under the Creative Commons Attribution International License (CC BY).

http://creativecommons.org/licenses/by/4.0/

(c) (i) Open Access

\begin{abstract}
Cyclophosphamide is an anti-neoplastic chemotherapy drug which, when administered to animals during the gestational period, provokes visceral, skeletal and external malformations. Copaiba oil obtained from Copaifera L. genus is traditionally used in popular medicine for its anti-inflammatory and antimicrobial activities. However, the effect of copaiba oil onteratogenesis remains unknown. This study aimed to investigate the possible protector effects of copaiba oil on the model of teratogenesis induced by cyclophosphamide in mice. Pregnant female Swiss mice were divided into 8 groups $(n=15)$. Three groups received copaiba oil, via gavage, in the following doses: 0.3 $\mathrm{mL} \cdot \mathrm{Kg}^{-1}, 0.6 \mathrm{~mL} \cdot \mathrm{Kg}^{-1}$ and $0.9 \mathrm{~mL} \cdot \mathrm{Kg}^{-1}$ (b.w.), associated to phosphate-buffered saline (PBS), intraperitoneal (i.p.). The negative control group received medium chain triglyceride (MCT) and PBS. The positive control group received cyclophosphamide $\left(30 \mathrm{mg} \cdot \mathrm{Kg}^{-1}\right.$ (b.w.) ) and MCT. The three treatment groups called associated groups $(\mathrm{A})$ received one of the doses of copaiba oil, via gavage and an associated dose of cyclophosphamide intraperitoneally. Copaiba oil presented a protective effect against teratogenesis induced by cyclophosphamide in the following skeletal structures: metacarpals, forepaws proximal phalanges, and tail vertebras. It also reduced the hydrocephalus frequency. These data suggest that copaiba oil could be a potential candidate for an anti-teratogenic agent.
\end{abstract}

\section{Keywords}

Copaiba Oil, Cyclophosphamide, Teratogenicity, Phytotherapy, Malformations 


\section{Introduction}

Fetal development abnormalities can be caused by drugs, pollutants, radiation and diseases that induce oxidative stress and production of free radicals [1] [2]. In experimental models, oxidative stress can be induced by cyclophosphamide, a drug used in anti-neoplastic chemotherapy and in the treatment of autoimmune diseases. Metabolism of cyclophosphamide at mitochondrial level through the P450 enzymes from the cytochrome system generates two teratogenic metabolic products-acrolein and phosphoramide mustard [3]. In addition to direct cytotoxicity of the intermediate and final metabolic products, the drug also produces teratogenic effects by inhibiting DNA synthesis and provoking apoptosis induced by oxidative stress [4]-[6]. Administration of cyclophosphamide to animals during the gestational period causes delayed fetal development, in addition to visceral, skeletal and external malformations, particularly in the members and in the head [7]-[9]. Ashby and co-workers showed that inhibition of the P450 cytochrome system, induction of antioxidant enzymes, or the use of antioxidant substances reduced the embryotoxic effects of cyclophosphamide and other substances known to cause oxidative stress in animal models [6]-[8] [10].

Copaiba oil is a resin-oil extract obtained from several species of Copaifera L. genus which is traditionally used in South American popular medicine as it demonstrates anti-inflammatory and antimicrobial activities. The main components of the oil are sesquiterpenes and diterpenes, substances that have been shown to possess antioxidant activity both in vivo and in vitro [6] [11]. Some sesquiterpenoid substances inhibit the embryolethal and teratogenic effects of cyclophosphamide administered to pregnant female rats, probably indirectly by inhibiting the reactions catalyzed by CYP2B1 [6]. This study aimed to investigate the possible protector effects of copaiba oil on the model of teratogenesis induced by cyclophosphamide in mice.

\section{Methods}

\subsection{Animals}

Male and nulliparous female Swiss mice (Mus musculus), weighing approximately 35 grams, supplied by the Central Vivarium of the Biological Sciences Center of the State University of Londrina (UEL), were used in the experiments. The animals were acclimatized for a 7-day period at the animal house, prior to the experiments. Animals were housed in standard polypropylene cages, containing wood shavings as bedding, with water and food ad libitum, under controlled light and temperature conditions (12 hours light/dark, at $22^{\circ} \mathrm{C} \pm 2{ }^{\circ} \mathrm{C}$ ). The experiment was conducted according to the norms of the Ethics Committee in Animal Experimentation of UEL (CEUA-UEL) and registered under the protocol number 10036.2012.10.

\subsection{Mating Procedure}

Mating was performed by placing four females into the cage of one male overnight, after which females were examined for evidence- a vaginal copulatory plug. Upon detection of plugs, the females were separated and day 0 of pregnancy (PG0) designated. Pregnant females were randomly divided into 8 experimental groups of 15 animals, with a total of 120 females used in this experiment.

\subsection{Study Design}

Three (satellite) groups received Vid'Amazon copaiba oil (CO) extracted from Copaifera sp. via gavage in one of the following concentrations: Group CO0.3: $0.3 \mathrm{~mL} \cdot \mathrm{Kg}^{-1}$ (b.w.); Group CO0.6: $0.6 \mathrm{~mL} \cdot \mathrm{Kg}^{-1}$ (b.w.) and Group CO0.9: $0.9 \mathrm{~mL} \cdot \mathrm{Kg}^{-1}$ (b.w.). The intermediate dose $\left(0.6 \mathrm{~mL} \cdot \mathrm{Kg}^{-1}\right)$ of copaiba oil was selected after literature consultation [12].

The CO treatment extended from the $8^{\text {th }}$ to the $12^{\text {nd }}$ day of the gestational period, and on the $10^{\text {th }}$ day, phosphate-buffered saline was intraperitoneally (i.p.) administered to animals of the CO0.3, CO0.6 and CO0.9 groups. Negative control group animals received medium chain triglyceride (MCT), by gavage, (this corresponds to the vehicle used to dilute the copaiba oil), in addition to PBS, under the same previously described experimental procedures. The positive control group received MCT from the $8^{\text {th }}$ to the $12^{\text {th }}$ days similar to the other experimental groups, in addition to a single dose of intraperitoneally administered cyclophosphamide (CP) 30 $\mathrm{mg} \cdot \mathrm{Kg}^{-1}$ (b.w.) on the $10^{\text {th }}$ pregnancy day. In order to evaluate the protective effect of copaiba oil on the alterations caused by $\mathrm{CP}$ during intra-uterine development, three (treatment) groups (A1, A2 and A3) received one of 
the three doses of copaiba oil from the $8^{\text {th }}$ to $12^{\text {th }}$ day of pregnancy in addition to a single dose of cyclophosphamide (CP) $30 \mathrm{mg} \cdot \mathrm{Kg}^{-1}$ (b.w.) on the $10^{\text {th }}$ day of pregnancy.

Pregnant females were weighed throughout the pregnancy for the evaluation of maternal weight gain. On day 18 of pregnancy, dams were euthanized by cervical dislocation, and laparotomies were performed. Gravidic uteri together with their contents were weighed. Fetuses were then removed and examined for: the number of live and dead fetuses, fetal and placental weight, and fetal length. Systematic analysis under a dissecting stereomicroscope was also performed to detect any external malformations. The emptied uteri were then examined for the presence of resorptions, and number of implantation sites determined using the Salewski method [13]. Postimplantation loss was calculated as follows: (number of implantations - number of live fetuses) $\times 100 /$ number of implantations and fetal viability by: number of live fetuses/number of implantations. The adequacy of fetal weight to pregnancy age was determined by following the method established by Calderon [14]. Half of the fetuses of each litter were randomly taken and fixed in Bodian for visceral analysis. The remaining half were fixed in acetone and subjected to skeletal analysis using the Alizarin red technique [15].

Visceral analysis of the thorax and abdomen was conducted following a combination of cuts/micro-dissections proposed by Barrow and Taylor [16]. The head visceral study was performed using strategic cuts proposed by Wilson [17]. The fetuses submitted to skeletal analysis were evaluated for: skull, sternum, vertebras, ribs, scapular and pelvic waists, phalanges, metacarpals and metatarsals abnormalities, according to the methodology described by Taylor [18].

Absolute data with normal distribution were analyzed by ANOVA (variance analysis) complemented with the Tukey or the student $\mathrm{T}$ test. Those with abnormal distribution were analyzed by Kruskal-Wallis, complemented by the Dunn test or Mann-Whitney test. A 5\% significance level was considered. The frequency difference between groups treated with cyclophosphamide only and the groups treated with cyclophosphamide associated with different doses of copaiba oil was analyzed by the chi-square test.

\section{Results}

Administration of MCT, different doses of copaiba oil, cyclophosphamide and the association of cyclophosphamide and copaiba oil did not induce maternal toxicity or alterations in the females' reproductive performance (Table 1). The administration of copaiba oil at the three doses did not cause any alterations in fetal development. Cyclophosphamide administration induced alterations in the developmental pattern of fetuses and placentas, which were not reverted by the association with copaiba oil (Table 2).

Copaiba oil did not cause skeletal, external or visceral alterations in any of the analyzed fetuses. The most frequent external alterations caused by the administration of cyclophosphamide were cleft palate, exophthalmos, polydactyly and syndactyly. The administration of copaiba oil inhibited polydactyly at the forepaws (Table 3).

Cyclophosphamide caused skeletal malformations in the head, thorax, scapular and pelvic waists (Table 4 and Table 5), characterized by the absence of formation, malformation (irregular forms) and reduced ossification. Although the administration of copaiba oil did not exert any effect on the reduced ossification, there was a reduction in the absent structures frequency, especially in the skull (basisphenoid and basiocciptal bones) and the irregular or malformed structures—hyoid, vertebras and the sternum (Table 4).

The analysis of ossification centers at hind and forepaws and at tail vertebras demonstrated that the administration of copaiba oil presented a protective effect against teratogenesis induced by cyclophosphamide at metacarpals, proximal phalanges in forepaws and at tail vertebras. The administration of cyclophosphamide inhibited the ossification of distal phalanges in both hind and forepaws, and reduced proximal phalanges in hind paws and metatarsal ossification without any protective effect of the copaiba oil (Table 6).

The visceral analysis showed a significant reduction of hydrocephalus frequency caused by the administration of cyclophosphamide in animals treated with copaiba oil (Table 7).

\section{Discussion}

The therapeutic effects of some phytotherapeutic substances have been attributed to the presence of natural antioxidant components that act by increasing the expression of endogenous antioxidant systems, either by acting as free radical scavengers or by inhibiting free radical formation [6] [19]-[23]. Antioxidant agents reduce the toxic effects of free radicals and may reduce the teratogenic effect of oxidative stress in the developing fetus [7] 
Table 1. Effects of copaiba oil treatment on reproductive performance, maternal toxicity and fertility patterns.

\begin{tabular}{|c|c|c|c|c|c|c|c|c|}
\hline & $\begin{array}{c}\text { MCT } \\
\mathrm{n}=15\end{array}$ & $\begin{array}{l}\mathrm{CO} 0.3 \\
\mathrm{n}=15\end{array}$ & $\begin{array}{l}\mathrm{CO} 0.6 \\
\mathrm{n}=15\end{array}$ & $\begin{array}{l}\mathrm{CO} 0.9 \\
\mathrm{n}=15\end{array}$ & $\begin{array}{c}\text { CP } \\
\mathrm{n}=15\end{array}$ & $\begin{array}{c}\mathrm{A} 0.3 \\
\mathrm{n}=15\end{array}$ & $\begin{array}{c}\text { A0.6 } \\
\mathrm{n}=15\end{array}$ & $\begin{array}{c}\text { A } 0.9 \\
\mathrm{n}=15\end{array}$ \\
\hline $\begin{array}{l}\text { Maternal weight } \\
\text { gain (g) }\end{array}$ & $19.1 \pm 8.00$ & $17.0 \pm 4.46$ & $17.4 \pm 7.86$ & $20.7 \pm 6.28$ & $16.7 \pm 4.81$ & $15.5 \pm 4.61$ & $14.3 \pm 6.97$ & $13.5 \pm 3.7$ \\
\hline $\begin{array}{l}\text { Pregnant uterus } \\
\text { weight (g) }\end{array}$ & $12.6 \pm 7.40$ & $11.7 \pm 4.18$ & $14.1 \pm 6.54$ & $14.2 \pm 5.92$ & $9.6 \pm 4.26$ & $9.1 \pm 4.08$ & $9.4 \pm 4.73$ & $9.6 \pm 3.07$ \\
\hline $\begin{array}{l}\text { Corrected } \\
\text { maternal weight } \\
\text { gain }(\mathrm{g})\end{array}$ & $6.6 \pm 2.65$ & $5.3 \pm 2.21$ & $3.3 \pm 3.35$ & $6.5 \pm 3.22$ & $7.1 \pm 2.30$ & $6.5 \pm 1.96$ & $4.9 \pm 5.41$ & $5 \pm 4.11$ \\
\hline $\begin{array}{l}\text { Maternal heart } \\
\text { weight (g) }\end{array}$ & $0.2 \pm 0.02$ & $0.2 \pm 0.30$ & $0.2 \pm 0.04$ & $0.2 \pm 0.02$ & $0.2 \pm 0.03$ & $0.2 \pm 0.03$ & $0.2 \pm 0.03$ & $0.2 \pm 0.03$ \\
\hline $\begin{array}{l}\text { Maternal lungs } \\
\text { weight (g) }\end{array}$ & $0.2 \pm 0.04$ & $0.24 \pm 0.03$ & $0.21 \pm 0.04$ & $0.2 \pm 0.03$ & $0.2 \pm 0.04$ & $0.2 \pm 0.05$ & $0.24 \pm 0.04$ & $0.2 \pm 0.03$ \\
\hline $\begin{array}{l}\text { Maternal kidneys } \\
\text { weight (g) }\end{array}$ & $0.4 \pm 0.07$ & $0.3 \pm 0.06$ & $0.4 \pm 0.05$ & $0.4 \pm 0.06$ & $0.4 \pm 0.05$ & $0.4 \pm 0.06$ & $0.4 \pm 0.05$ & $0.4 \pm 0.05$ \\
\hline $\begin{array}{l}\text { Maternal liver } \\
\text { weight (g) }\end{array}$ & $2.1 \pm 0.40$ & $2.2 \pm 0.37$ & $2.1 \pm 0.49$ & $2.3 \pm 0.20$ & $2.2 \pm 0.31$ & $2.2 \pm 0.31$ & $2.1 \pm 0.43$ & $2.17 \pm 0.32$ \\
\hline $\begin{array}{l}\text { Number of } \\
\text { implants }\end{array}$ & $9.1 \pm 4.87$ & $9.7 \pm 2.58$ & $9.8 \pm 4.28$ & $11.4 \pm 2.79$ & $9.4 \pm 3.94$ & $9.9 \pm 3.47$ & $11.5 \pm 3.700$ & $10.5 \pm 3.04$ \\
\hline $\begin{array}{l}\text { Number of live } \\
\text { fetuses }\end{array}$ & $7.3 \pm 4.73$ & $5.9 \pm 2.45$ & $8.4 \pm 4.20$ & $8.5 \pm 4.05$ & $6.47 \pm 3.27$ & $6.8 \pm 3.10$ & $7.1 \pm 3.89$ & $5.5 \pm 2.29$ \\
\hline $\begin{array}{c}\text { Fetal } \\
\text { viability (\%) }\end{array}$ & $80.0 \pm 26.76$ & $62.9 \pm 25.81$ & $87.0 \pm 19.07$ & $72.1 \pm 23.27$ & $73.0 \pm 24.20$ & $71.51 \pm 23.29$ & $63.90 \pm 28.17$ & $65.21 \pm 20.18$ \\
\hline
\end{tabular}

The values are represented in average \pm standard deviation. The statistical description of the groups was made using the Mann-Whitney-U test, followed by the Dunn test (non-parametric data). The minimum significance level considered was p < 0.05. MCT: animals treated with MCT (negative control), CO0.3: animals treated with 0.3 grams of copaiba oil; CO0.6: animals treated with 0.6 grams of copaiba oil; CO0.9: animals treated with 0.9 grams of copaiba oil; CP: animals treated with cyclophosphamide; A0.3: animals treated with cyclophosphamide and 0.3 g of copaiba oil; A6: animals treated with cyclophosphamide and $0.6 \mathrm{~g}$ of copaiba oil; A0.9: animals treated with cyclophosphamide and $0.9 \mathrm{~g}$ of copaiba oil.

Table 2. Effects of copaiba oil and cyclophosphamide on intra-uterine development.

\begin{tabular}{ccccccccc}
\hline & $\begin{array}{c}\text { MCT } \\
\mathrm{n}=109\end{array}$ & $\begin{array}{c}\text { CO0.3 } \\
\mathrm{n}=88\end{array}$ & $\begin{array}{c}\text { CO0.6 } \\
\mathrm{n}=116\end{array}$ & $\begin{array}{c}\text { CO0.9 } \\
\mathrm{n}=128\end{array}$ & $\begin{array}{c}\mathrm{CP} \\
\mathrm{n}=77\end{array}$ & $\begin{array}{c}\mathrm{A} 0.3 \\
\mathrm{n}=89\end{array}$ & $\begin{array}{c}\text { A0.6 } \\
\mathrm{n}=81\end{array}$ \\
$\begin{array}{c}\text { Individual fetal } \\
\text { weight (g) }\end{array}$ & $1.4 \pm 0.15$ & $1.5 \pm 0.11$ & $1.3 \pm 0.19$ & $1.2 \pm 0.21$ & $0.8 \pm 0.20^{\mathrm{a}}$ & $0.8 \pm 0.19^{\mathrm{a}}$ & $0.8 \pm 0.15^{\mathrm{a}}$ & $0.8 \pm 0.18^{\mathrm{a}}$ \\
$\begin{array}{c}\text { Fetal length (cm) } \\
\begin{array}{c}\text { Individual placental } \\
\text { weight (g) }\end{array}\end{array}$ & $0.1 \pm 0.02$ & $0.1 \pm 0.03$ & $0.1 \pm 0.02$ & $0.1 \pm 0.02$ & $0.1 \pm 0.02^{\mathrm{a}}$ & $0.1 \pm 0.10^{\mathrm{a}}$ & $0.1 \pm 0.02^{\mathrm{a}}$ & $0.1 \pm 0.08^{\mathrm{a}}$ \\
\hline
\end{tabular}

The values are represented in average \pm standard deviation. The statistical description of the groups was made using ANOVA test, followed by Tukey-Kramer test (parametric data). The minimal significance level considered was $\mathrm{p}<0.05$. MCT: animals treated with MCT (negative control), CO0.3: animals treated with 0.3 grams of copaiba oil; CO0.6: animals treated with 0.6 grams of copaiba oil; CO0.9: animals treated with 0.9 grams of copaiba oil; CP: animals treated with cyclophosphamide; A0.3: animals treated with cyclophosphamide and 0.3 g of copaiba oil; A6: animals treated with cyclophosphamide and $0.6 \mathrm{~g}$ of copaiba oil; A0.9: animals treated with cyclophosphamide and $0.9 \mathrm{~g}$ of copaiba oil. ${ }^{\mathrm{a}} \mathrm{p}<0.005$ significant statistical difference in comparison to MCT group.

[10]. For example, the administration of indo-3-carbinol, an antioxidant agent found in raw vegetables, to pregnant female mice exposed to cyclophosphamide during the organogenesis period, reduces the number of fetal malformations [10]. Furthermore, in vitro studies which involved the addition of ginseng to mice embryo cultures demonstrated an increase in the expression of antioxidant enzymes and a reduction in malformations caused by ethanol induced oxidative stress [24].

However, the administration of phytotherapeutic compounds during pregnancy must be evaluated with caution since some compounds of natural products may have proteratogenic effects [8]. For instance, the kaurenoic acid, a diterpene isolated from copaiba oleo-resin, showed cytotoxic and embryotoxic effects in developing sea urchin (Lytechinus variegatus) embryos, on tumor cell growth and on mouse and human erythrocytes [25].

Copaiba oil is largely used in South American traditional medicine due to its anti-inflammatoratory [26], antimicrobial [27], antinociceptive [28], antiparasitic [29] and antioxidant [30] activities. In the first step of this 
Table 3. External alterations observed in mice offspring due to maternal treatment with cyclophosphamide and copaiba oil.

\begin{tabular}{|c|c|c|c|c|}
\hline & $\mathrm{CP} N=42$ & $\mathrm{~A} 0.3 \mathrm{n}=38$ & A0.6n $=26$ & A $0.9 n=35$ \\
\hline Open eyes & 22 (52.3\%) & 17 (44.3\%) & $11(42.3 \%)$ & $15(42.8 \%)$ \\
\hline \multicolumn{5}{|l|}{ Exophthalmos } \\
\hline Unilateral & - & - & - & - \\
\hline Bilateral & $19(45.2 \%)$ & 15 (39.5\%) & $10(38.4 \%)$ & $12(37.3 \%)$ \\
\hline Lower ears' implantation & $6(14.2 \%)$ & $5(13.1 \%)$ & $4(15.3 \%)$ & $5(14.3 \%)$ \\
\hline Cleft palate & 25 (59.2\%) & 22 (57.9\%) & $14(53.8 \%)$ & $20(57.1 \%)$ \\
\hline \multicolumn{5}{|l|}{ Forelimbs } \\
\hline Amelia & - & - & - & - \\
\hline Focomelia & $10(23.8 \%)$ & $11(28.9 \%)$ & 7 (26.9\%) & $8(22.8 \%)$ \\
\hline RAP & 5 (11.9\%) & $3(7.9 \%)$ & $3(11.5 \%)$ & 5 (14.3\%) \\
\hline Polidactyly in forepaws & 44 (52.4\%) & b & $\mathrm{b}$ & $\mathrm{b}$ \\
\hline Syndactyly & 45 (53.6\%) & 41 (53.9\%) & $25(48.1 \%)$ & $32(45.7 \%)$ \\
\hline \multicolumn{5}{|l|}{ Hind limbs } \\
\hline Amely & - & - & - & - \\
\hline Focomely & - & $1(2.6 \%)$ & $3(11.5 \%)$ & - \\
\hline RPP & $11(26.2 \%)$ & $8(21.0 \%)$ & $2(7.7 \%)$ & $6(17.1 \%)$ \\
\hline Polidactyly in hind paws & 49 (58.3\%) & $36(47.3 \%)$ & $22(42.3 \%)$ & $37(52.8 \%)$ \\
\hline Sindactyly & 32 (38.1\%) & 23 (30.2\%) & 16 (30.7\%) & 20 (28.5\%) \\
\hline
\end{tabular}

$\mathrm{X}^{2}$ test. Difference between the frequency of observations in groups A0.3, A0.6 and A0.9 in comparison to the CP group. ${ }^{\mathrm{b}} \mathrm{p}<0.01$ significant statistical difference in comparison to the CP group.

study, the cytotoxicity effect of copaiba oil on pregnant females and their offspring was evaluated. Our study showed that copaiba oil did not have a toxic or teratogenic activity for the administered doses. This corroborates the previous study by Sachetti [31]. The second stage of the study evaluated the toxicity of cyclophosphamide and the association between cyclophosphamide and copaiba oil in pregnant females. The administered dose of cyclophosphamide did not cause maternal toxicity or any significant alteration to reproductive patterns, but it did cause delayed development and fetal abnormalities, as previously described by other authors [3] [9]. The treatment of animals with copaiba oil submitted to the administration of cyclophosphamide did not attenuate the delay of fetal development, but significantly reduced the malformation frequency in structures derived from the neural tube, particularly the brain and some facial structures.

Copaiba oil is a phytotherapeutic extract that could be a strong candidate for an anti-teratogenic agent since it contains a class of substances known as terpenes (sesquiterpenes, diterpenes and triterpenes) whose antioxidant therapeutic properties have been previously described [6] [21]-[23]. It is probable that these substances increase the antioxidant enzyme system activity at phase II of biotransformation, or inhibit the activation of the P450 cytochrome system [3] [11]. The sesquiterpenoids (beta-caryophyllene, alfa-copaene, alfa-cadinene and alfahumulene) possess antioxidant effects by directly kidnapping free radicals (free radical scavengers), increasing the production of antioxidant enzymes, or inhibiting the production of nitric oxide [22] [23] [32]-[34]. Some sesquiterpenoid substances inhibit the embryolethal and teratogenic effects of cyclophosphamide administered to pregnant female rats [6]. In addition, plant extracts with high levels of beta-caryophyllene inhibit free radical formation and lipid peroxidation of critical mechanisms in lesions induced by free radicals [34] [35].

Cyclophosphamide exerts neurotoxic effects, characterized by hydrocephalus, malformations of facial structures and members caused by the action of the drug and its metabolites [3]. In our study, we observed that the embryotoxic effects of cyclophosphamide on organs deriving from the neural tube were totally or partially reverted by the administration of copaiba oil. However, the administration of copaiba oil could not significantly reverse the alterations observed in members. Teratogenesis in embryonic tissues occurs in a selective way, which means that the cells comprising a determined tissue suffer alterations when exposed to a teratogen, while cells in other tissues are relatively resistant to the same teratogen. Some authors [4] [9] [36], demonstrated that 
Table 4. Skeletal alterations of head and thoracic skeleton observed in mice offspring due to maternal treatment with cyclophosphamide and copaiba oil.

\begin{tabular}{|c|c|c|c|c|}
\hline & $\mathrm{CP} n=35$ & $\mathrm{~A} 0.3 \mathrm{n}=51$ & $\mathrm{~A} 0.6 \mathrm{n}=55$ & $A 0.9 n=36$ \\
\hline $\begin{array}{l}\text { Maxilla } \\
\text { Irregular }\end{array}$ & $28(80.0 \%)$ & 42 (82.3\%) & 45 (81.8\%) & $26(72.2 \%)$ \\
\hline $\begin{array}{l}\text { Mandible } \\
\text { Irregular }\end{array}$ & 25 (71.4\%) & 39 (76.5\%) & 42 (76.3\%) & 27 (75.0\%) \\
\hline $\begin{array}{l}\text { Pterygoid } \\
\text { Irregular } \\
\text { RO }\end{array}$ & $\begin{array}{c}4(11.4 \%) \\
19(54.3 \%)\end{array}$ & $\begin{array}{c}4(7.8 \%) \\
38(74.5 \%)\end{array}$ & $\begin{array}{l}16(29.1 \%) \\
29(52.7 \%)\end{array}$ & $\begin{array}{c}1(2.7 \%) \\
21(58.3 \%)\end{array}$ \\
\hline $\begin{array}{l}\text { Basisphenoid } \\
\text { Absent } \\
\text { Irregular } \\
\text { OR }\end{array}$ & $\begin{array}{c}11(31.1 \%) \\
1(2.8 \%) \\
23(65.7 \%)\end{array}$ & $\begin{array}{c}\mathrm{b} \\
10(19.3 \%)^{\mathrm{b}} \\
39(76.5 \%)\end{array}$ & $\begin{array}{c}\mathrm{b} \\
12(21.8 \%)^{\mathrm{b}} \\
35(63.6 \%)\end{array}$ & $\begin{array}{c}\mathrm{b} \\
5(13.8 \%) \\
25(69.4 \%)\end{array}$ \\
\hline $\begin{array}{l}\text { Hyoid } \\
\text { Absent } \\
\text { Irregular }\end{array}$ & $\begin{array}{c}4(11.4 \%) \\
23(65.7 \%)\end{array}$ & $\begin{array}{l}10(19.6 \%) \\
15(29.4 \%)^{b}\end{array}$ & $\begin{array}{l}11(20.0 \%) \\
23(41.8 \%)^{b}\end{array}$ & $\begin{array}{c}1(2.7 \%) \\
6(16.7 \%)^{b}\end{array}$ \\
\hline $\begin{array}{l}\text { Tympanic annu } \\
\text { Absent } \\
\text { Irregular }\end{array}$ & $\begin{array}{c}3(8.5 \%) \\
21(60.0 \%)\end{array}$ & $\begin{array}{c}3(5.8 \%) \\
38(74.5 \%)\end{array}$ & $\begin{array}{l}12(21.8 \%) \\
29(52.7 \%)\end{array}$ & $20(55.5 \%)$ \\
\hline $\begin{array}{l}\text { Basioccipital } \\
\quad \text { Absent } \\
\text { Irregular } \\
\text { RO }\end{array}$ & $\begin{array}{c}4(11.4 \%) \\
1(2.8 \%) \\
30(85.7 \%)\end{array}$ & $\begin{array}{c}2(3.9 \%)^{\mathrm{b}} \\
5(9.8 \%) \\
43(84.3 \%)\end{array}$ & $\begin{array}{c}\mathrm{b} \\
- \\
51(92.7 \%)\end{array}$ & $\begin{array}{c}\mathrm{b} \\
- \\
31(86.1 \%)\end{array}$ \\
\hline $\begin{array}{l}\text { Exoccipital } \\
\text { Irregular } \\
\text { RO }\end{array}$ & $\begin{array}{c}1(2.8 \%) \\
34(97.1 \%)\end{array}$ & $\begin{array}{c}3(5.8 \%) \\
43(84.3 \%)\end{array}$ & 52 (94.5\%) & 32 (88.9\%) \\
\hline $\begin{array}{c}\text { Nasal } \\
\text { RO }\end{array}$ & $22(62.8 \%)$ & 34 (66.6\%) & 28 (50.9\%) & $21(58.3 \%)$ \\
\hline $\begin{array}{c}\text { Zygomátic } \\
\text { Absent } \\
\text { Irregular }\end{array}$ & $\begin{array}{c}29(82.8 \%) \\
6(17.1 \%)\end{array}$ & $\begin{array}{c}45(88.2 \%) \\
6(11.7 \%)\end{array}$ & $\begin{array}{l}37(67.3 \%) \\
18(32.7 \%)\end{array}$ & $\begin{array}{c}28(77.7 \%) \\
8(22.2 \%)\end{array}$ \\
\hline $\begin{array}{c}\text { Frontal } \\
\text { RO }\end{array}$ & 22 (62.8\%) & 34 (66.6\%) & 28 (50.9\%) & $21(58.3 \%)$ \\
\hline $\begin{array}{l}\text { Parietal } \\
\text { Absent } \\
\text { RO }\end{array}$ & $\begin{array}{c}1(2.8 \%) \\
32(91.4 \%)\end{array}$ & $\begin{array}{c}1(1.9 \%) \\
48(94.1 \%)\end{array}$ & $51(92.7 \%)$ & 27 (75.0\%) \\
\hline $\begin{array}{l}\text { Interparietal } \\
\text { Absent } \\
\text { RO }\end{array}$ & $\begin{array}{c}1(2.8 \%) \\
29(82.8 \%)\end{array}$ & $\begin{array}{c}1(1.9 \%) \\
48(94.1 \%)\end{array}$ & $43(78.2 \%)$ & $24(66.6 \%)$ \\
\hline $\begin{array}{l}\text { Supraoccipital } \\
\text { Absent } \\
\text { RO }\end{array}$ & $\begin{array}{c}2(5.7 \%) \\
33(94.2 \%)\end{array}$ & 48 (94.1\%) & 52 (94.5\%) & $32(88.0 \%)$ \\
\hline $\begin{array}{l}\text { Sternum } \\
\quad \text { Malformed }\end{array}$ & $26(74.2 \%)$ & 38 (75.4\%) & 37 (67.2\%) & $15(41.6 \%)^{\mathrm{b}}$ \\
\hline $\begin{array}{l}\text { Vertebraes } \\
\text { Malformed }\end{array}$ & 19 (54.2\%) & 33 (64.2\%) & 30 (54.5\%) & $13(36.1 \%)^{\mathrm{c}}$ \\
\hline $\begin{array}{l}\text { Ribs } \\
\quad \text { Malformed }\end{array}$ & 15 (42.8\%) & 28 (54.9\%) & 30 (54.5\%) & 20 (55.5\%) \\
\hline
\end{tabular}

$\mathrm{X}^{2}$ test. Difference between frequency of observations in groups A0.3, A0.6 and A0.9 in comparison to the CP group. ${ }^{\mathrm{b}} \mathrm{p}<0.005$, ${ }^{\mathrm{C}} \mathrm{p}<0.05$ significant statistical difference in comparison to the $\mathrm{CP}$ group. $\mathrm{RO}=$ reduced ossification.

teratogenesis caused by cyclophosphamide is related to the susceptibility of certain tissues to suffer apoptosis and alterations in the differential expression of the p53 gene, particularly in nervous tissues. Cytotoxic products of cyclophosphamide may be eliminated by the biotransformation system of phase II and by the action of antioxidants present at the mitochondrial matrix, such as the glutathione and catalase systems [8] [37]. The products of cyclophosphamide metabolized by P450 cytochrome, including acrolein and phosphoramide mustard, induce lipid peroxidation of mitochondrial membranes and liberation of c cytochrome that induces the activation of 
Table 5. Skeletal alterations of scapular and pelvic waist observed in mice offspring due to maternal treatment with cyclophosphamide and copaiba oil.

\begin{tabular}{|c|c|c|c|c|}
\hline & $\mathrm{CP} n=35$ & $\mathrm{~A} 0.3 \mathrm{n}=51$ & $A 0.6 n=55$ & $A 0.9 n=36$ \\
\hline \multicolumn{5}{|c|}{ Scapular waist } \\
\hline \multicolumn{5}{|l|}{ Scapula } \\
\hline Absent & 2 (5.7\%) & 3 (5.8\%) & $1(1.8 \%)$ & $4(11.1 \%)$ \\
\hline Irregular & $20(57.1 \%)$ & 36 (70.5\%) & 34 (61.8\%) & $26(72.2 \%)$ \\
\hline \multicolumn{5}{|l|}{ Clavicle } \\
\hline Absent & $4(11.4 \%)$ & 8 (15.6\%) & 2 (3.6\%) & 1 (2.7\%) \\
\hline Irregular & $16(45.7 \%)$ & $19(37.2 \%)$ & $18(32.7 \%)$ & $12(33.3 \%)$ \\
\hline \multicolumn{5}{|l|}{ Humerus } \\
\hline Absent & 1 (2.8\%) & - & - & - \\
\hline Irregular & 3 (8.5\%) & $5(9.8 \%)$ & 7 (12.7\%) & $1(2.7 \%)$ \\
\hline \multicolumn{5}{|l|}{ Radius } \\
\hline Absent & $1(2.8 \%)$ & $1(1.9 \%)$ & $1(1.8 \%)$ & - \\
\hline Irregular & 3 (8.5\%) & $4(7.8 \%)$ & - & $1(2.7 \%)$ \\
\hline \multicolumn{5}{|l|}{ Ulna } \\
\hline Absent & $1(2.8 \%)$ & $1(1.9 \%)$ & $1(1.8 \%)$ & $1(2.7 \%)$ \\
\hline Irregular & $3(8.5 \%)$ & $4(7.8 \%)$ & - & - \\
\hline Symelia & 19 (54.2\%) & 30 (58.8\%) & 19 (34.5\%) & $13(36.1 \%)$ \\
\hline Amelia & - & $1(1.9 \%)$ & $1(1.8 \%)$ & - \\
\hline \multicolumn{5}{|l|}{ Pelvic waist } \\
\hline \multicolumn{5}{|l|}{ Ilium } \\
\hline Absent & $1(2.8 \%)$ & 7 (13.7\%) & $1(1.8 \%)$ & 2 (5.5\%) \\
\hline Irregular & $9(25.7 \%)$ & $16(31.1 \%)$ & $16(29.1 \%)$ & 7 (19.4\%) \\
\hline \multicolumn{5}{|l|}{ Ischium } \\
\hline Absent & $1(2.8 \%)$ & 4 (7.8\%) & $1(1.8 \%)$ & 1 (5.5\%) \\
\hline Irregular & $9(27.5 \%)$ & 20 (39.1\%) & $16(29.1 \%)$ & 7 (19.4\%) \\
\hline \multicolumn{5}{|l|}{ Pubis } \\
\hline Absent & $1(2.8 \%)$ & 4 (7.8\%) & $1(1.8 \%)$ & 2 (5.5\%) \\
\hline Irregular & $9(27.5 \%)$ & 20 (39.1\%) & $16(29.1 \%)$ & 7 (19.4\%) \\
\hline \multicolumn{5}{|l|}{ Femur } \\
\hline Absent & 5 (14.3\%) & $12(23.5 \%)$ & 2 (3.6\%) & $4(11.1 \%)$ \\
\hline Irregular & $11(31.4 \%)$ & $15(29.4 \%)$ & $13(23.6 \%)$ & $4(11.1 \%)$ \\
\hline \multicolumn{5}{|l|}{ Tibia } \\
\hline Absent & 5 (14.3\%) & $6(11.8 \%)$ & 1 (1.8\%) & 4 (11.1\%) \\
\hline Irregular & $11(31.4 \%)$ & $15(29.4 \%)$ & $12(21.8 \%)$ & 7 (19.4\%) \\
\hline \multicolumn{5}{|l|}{ Fibula } \\
\hline Absent & 5 (14.3\%) & $6(11.8 \%)$ & 1 (1.8\%) & 4 (11.1\%) \\
\hline Irregular & $11(31.4 \%)$ & $15(29.4 \%)$ & 12 (21.8\%) & $7(19.4 \%)$ \\
\hline Symelia & 7 (20.0\%) & $6(11.7 \%)$ & 15 (27.2\%) & $6(16.6 \%)$ \\
\hline Amelia & - & $4(7.8 \%)$ & $5(9.1 \%)$ & - \\
\hline
\end{tabular}

$\mathrm{X}^{2}$ test. Frequency of observations in the groups A0.3, A0.6 and A0.9 in comparison to CP group.

caspases 3, 8 and 9, and the p53 genes [38]. It is possible that the anti-teratogenic effects of copaiba oil are related to decrease in mitochondrial lesions caused by oxidative stress which makes the effects more evident on structures derived from the neural tube.

\section{Conclusions}

The results obtained in this study suggest that copaiba oil partially inhibits the teratogenic effects caused by cyclophosphamide. Although the teratogenicity of cyclophosphamide is mainly attributed to oxidative stress induced by the drug, the healing and cell proliferation inductor properties of copaiba oil also need to be investigated as a possible factor involved in the recovery of tissues damaged by the drug. This study opens possibilities for the use of copaiba oil components to inhibit the teratogenic effect caused by oxidative stress. This finding becomes particularly important considering the great number of systemic conditions caused by the environment and drugs that can induce oxidative stress and their deleterious effects on fetal development model. 
Table 6. Effects of the treatment with copaiba oil and cyclophosphamide on the number of ossification centers in offspring.

\begin{tabular}{|c|c|c|c|c|c|c|c|c|}
\hline & $\begin{array}{l}\text { MCT } \\
\mathrm{n}=59\end{array}$ & $\begin{array}{l}\mathrm{CO} 0.3 \\
\mathrm{n}=48\end{array}$ & $\begin{array}{l}\mathrm{CO} 0.6 \\
\mathrm{n}=72\end{array}$ & $\begin{array}{l}\mathrm{CO} 0.9 \\
\mathrm{n}=69\end{array}$ & $\begin{array}{c}\text { CP } \\
\mathrm{n}=35\end{array}$ & $\begin{array}{c}\mathrm{A} 0.3 \\
\mathrm{n}=51\end{array}$ & $\begin{array}{c}\mathrm{A} 0.6 \\
\mathrm{n}=55\end{array}$ & $\begin{array}{c}\text { A0.9 } \\
\mathrm{n}=36\end{array}$ \\
\hline Metacarpals & $\begin{array}{c}3.966 \pm \\
0.023\end{array}$ & $\begin{array}{c}3.958 \pm \\
0.029\end{array}$ & $\begin{array}{c}3.931 \pm \\
0.030\end{array}$ & $\begin{array}{c}3.942 \pm \\
0.028\end{array}$ & $\begin{array}{c}2.029 \pm \\
0.299^{\mathrm{a}}\end{array}$ & $\begin{array}{l}2.220 \pm \\
0.174^{\mathrm{a}, \mathrm{b}}\end{array}$ & $\begin{array}{l}2.632 \pm \\
0.233^{\mathrm{a}, \mathrm{b}}\end{array}$ & $\begin{array}{l}2.484 \pm \\
0.310^{\mathrm{a}, \mathrm{b}}\end{array}$ \\
\hline $\begin{array}{l}\text { Proximal phalanges } \\
\text { in forepaws }\end{array}$ & $\begin{array}{c}3.983 \pm \\
0.016\end{array}$ & $\begin{array}{c}3.979 \pm \\
0.020\end{array}$ & $\begin{array}{c}3.975 \pm \\
0.019\end{array}$ & $\begin{array}{c}4.000 \pm \\
0.000\end{array}$ & $\begin{array}{c}0.771 \pm \\
0.266^{\mathrm{a}}\end{array}$ & $\begin{array}{c}0.680 \pm \\
0.208^{\mathrm{a}}\end{array}$ & $\begin{array}{l}1.614 \pm \\
0.262^{\mathrm{a}, \mathrm{b}}\end{array}$ & $\begin{array}{l}1.250 \pm \\
0.330^{\mathrm{a}, \mathrm{b}}\end{array}$ \\
\hline $\begin{array}{l}\text { Distal phalanges in } \\
\text { forepaws }\end{array}$ & $\begin{array}{c}3.000 \pm \\
0.000\end{array}$ & $\begin{array}{c}3.000 \pm \\
0.000\end{array}$ & $\begin{array}{c}3.000 \pm \\
0.000\end{array}$ & $\begin{array}{c}3.000 \pm \\
0.000\end{array}$ & a & a & a & a \\
\hline Metatarsals & $\begin{array}{c}5.000 \pm \\
0.000\end{array}$ & $\begin{array}{l}5.000 \pm \\
0.000\end{array}$ & $\begin{array}{c}5.000 \pm \\
0.000\end{array}$ & $\begin{array}{c}5.000 \pm \\
0.000\end{array}$ & $\begin{array}{c}4.529 \pm \\
0.267\end{array}$ & $\begin{array}{c}4.340 \pm \\
0.126\end{array}$ & $\begin{array}{c}4.501 \pm \\
0.261\end{array}$ & $\begin{array}{c}4.774 \pm \\
0.195\end{array}$ \\
\hline $\begin{array}{l}\text { Proximal phalanges } \\
\text { in hind paws }\end{array}$ & $\begin{array}{c}4.814 \pm \\
0.051\end{array}$ & $\begin{array}{c}4.833 \pm \\
0.054\end{array}$ & $\begin{array}{c}4.819 \pm \\
0.045\end{array}$ & $\begin{array}{c}4.812 \pm \\
0.047\end{array}$ & $\begin{array}{c}1.343 \pm \\
0.108^{\mathrm{a}}\end{array}$ & $\begin{array}{l}1.540 \pm \\
0.086^{\mathrm{a}}\end{array}$ & $\begin{array}{l}1.474 \pm \\
0.079^{\mathrm{a}}\end{array}$ & $\begin{array}{r}1.335 \pm \\
0.118^{\mathrm{a}}\end{array}$ \\
\hline $\begin{array}{c}\text { Distal phalanges in } \\
\text { hind paws }\end{array}$ & $\begin{array}{c}1.746 \pm \\
0.057\end{array}$ & $\begin{array}{c}1.792 \pm \\
0.059\end{array}$ & $\begin{array}{c}1.806 \pm \\
0.046\end{array}$ & $\begin{array}{c}1.739 \pm \\
0.053\end{array}$ & a & a & a & a \\
\hline Tail vertebraes & $\begin{array}{c}7.136 \pm \\
0.044\end{array}$ & $\begin{array}{c}7.104 \pm \\
0.044\end{array}$ & $\begin{array}{c}7.069 \pm \\
0.030\end{array}$ & $\begin{array}{c}7.101 \pm \\
0.036\end{array}$ & $\begin{array}{c}5.029 \pm \\
0.086^{\mathrm{a}}\end{array}$ & $\begin{array}{l}5.480 \pm \\
0.082^{\mathrm{a}, \mathrm{b}}\end{array}$ & $\begin{array}{l}5.737 \pm \\
0.085^{\mathrm{a}, \mathrm{b}}\end{array}$ & $\begin{array}{l}6.097 \pm \\
0.085^{\mathrm{a}, \mathrm{b}}\end{array}$ \\
\hline
\end{tabular}

The values are represented in average \pm standard deviation. The statistical description of the groups was made using the Mann-Whitney-U test, followed by the Dunn test (non-parametric data). The minimal significance level considered was p < 0.05. MCT: animals treated with MCT (negative control), CO0.3: animals treated with 0.3 grams of copaiba oil; CO0.6: animals treated with 0.6 grams of copaiba oil; CO0.9: animals treated with 0.9 grams of copaiba oil; CP: animals treated with cyclophosphamide; A0.3: animals treated with cyclophosphamide and 0.3 g of copaiba oil; A6: animals treated with cyclophosphamide and $0.6 \mathrm{~g}$ of copaiba oil; A0.9: animals treated with cyclophosphamide and $0.9 \mathrm{~g}$ of copaiba oil. ${ }^{\mathrm{a}} \mathrm{p}<0.005$ significant statistical difference in comparison to the MCT group. ${ }^{\mathrm{b}} \mathrm{p}<0.01$ significant statistical difference in comparison to the CP group.

Table 7. Visceral alterations observed in mice offspring due to maternal treatment with cyclophosphamide and copaiba oil.

\begin{tabular}{|c|c|c|c|c|}
\hline & $\begin{array}{c}\text { CP } \\
n=42\end{array}$ & $\begin{array}{c}\mathrm{A} 0.3 \\
\mathrm{n}=38\end{array}$ & $\begin{array}{c}\mathrm{A} 0.6 \\
\mathrm{n}=26\end{array}$ & $\begin{array}{c}\mathrm{A} 0.9 \\
\mathrm{n}=35\end{array}$ \\
\hline \multicolumn{5}{|l|}{ Hydrocephalus } \\
\hline \multicolumn{5}{|l|}{ Lateral ventricles } \\
\hline Light & 24 (57.1\%) & $7(18.4 \%)^{\mathrm{b}}$ & $5(19.2 \%)^{b}$ & $6(17.1 \%)^{\mathrm{b}}$ \\
\hline Moderate & - & - & - & - \\
\hline Severe & $06(14.2 \%)$ & - & - & $1(2.8 \%)$ \\
\hline \multicolumn{5}{|c|}{ Third and fourth ventricles } \\
\hline Light & 05 (11.9\%) & $3(7.9 \%)$ & $2(7.7 \%)$ & $2(5.7 \%)$ \\
\hline Moderate & $\begin{array}{c}- \\
-\end{array}$ & - & $-(1)$. & $-(0.0)$ \\
\hline Severe & $\begin{array}{l}- \\
-\end{array}$ & - & - & - \\
\hline \multicolumn{5}{|l|}{ Eyes } \\
\hline \multicolumn{5}{|l|}{ Anophthalmia } \\
\hline Unilateral & $1(2.4 \%)$ & $1(2.6 \%)$ & $1(3.8 \%)$ & $1(2.8 \%)$ \\
\hline Bilateral & - & - & - & - \\
\hline \multicolumn{5}{|l|}{ Kidneys } \\
\hline Hydronephrosis & $2(4.7 \%)$ & $3(7.9 \%)$ & $2(2.7 \%)$ & $2(5.7 \%)$ \\
\hline Agenesis & $2(4.7 \%)$ & - & - & $2(5.7 \%)$ \\
\hline
\end{tabular}

$\mathrm{X}^{2}$ test. Difference between the frequency of observations in the groups A0.3, A0.6 and A0.9 in comparison to the CP group. ${ }^{\mathrm{b}} \mathrm{p}<0.005$ significant statistical difference in comparison to the CP group.

Copaiba oil may also be used as an adjuvant in cancer chemotherapy, since concomitant nutritional therapy with antioxidants shows various benefits in the treatment of cancer patients, resulting in lowered side effects and allowing the continuation of cytotoxic treatment with diminished harm to the patient.

\section{Conflict of Interest}

The authors declare no conflicts of interest.

\section{References}

[1] Wells, P.G., Bhuller, Y., Chen, C.S., Jeng, W., Kasapinovic, S., Kennedy, J.C., Kim, P.M., Laposa, R.R., McCallum, G.P., Nicol, C.J., Parman, T., Wiley, M.J. and Wong, A.W. (2005) Molecular and Biochemical Mechanisms in Tera- 
togenesis Involving Reactive Oxygen Species. Toxicology and Applied Pharmacology, 207, 354-366. http://dx.doi.org/10.1016/j.taap.2005.01.061

[2] Ornoy, A. (2007) Embryonic Oxidative Stress as a Mechanism of Teratogenesis with Special Emphasis on Diabetic Embryopathy. Reproductive Toxicology, 24, 31-41. http://dx.doi.org/10.1016/j.reprotox.2007.04.004

[3] Hales, B.F. (1981) Modification of the Mutagenicity and Teratogenicity of Cyclophosphamide in Rats with Inducers of the Cytochromes P-450. Teratology, 24, 1-11. http://dx.doi.org/10.1002/tera.1420240102

[4] Mirkes, P.E. and Little, S.A. (1998) Teratogen-Induced Cell Death in Postimplantation Mouse Embryos: Differential Tissue Sensitivity and Hallmarks of Apoptosis. Cell Death Differentiation, 5, 592-600. http://dx.doi.org/10.1038/sj.cdd.4400390

[5] Manson, J.M. and Smith, C.C. (1977) Influence of Cyclophosphamide and 4-Ketocyclophosphamide on Mouse Limb Development. Teratology, 15, 291-299. http://dx.doi.org/10.1002/tera.1420150311

[6] Gomes-Carneiro, M.R., De-Oliveira, A.C., De-Carvalho, R.R., Araujo, I.B., Souza, C.A., Kuriyama, S.N. and Paumgartten, F.J. (2003) Inhibition of Cyclophosphamide-Induced Teratogenesis by Beta-Ionone. Toxicological Letters, 138, 205-213. http://dx.doi.org/10.1016/S0378-4274(02)00413-7

[7] Ashby, R., Davis, L., Dewhurst, B.B., Espinal, R., Penn, R.N. and Upshall, D.G. (1976) Aspects of the Teratology of Cyclophosphamide (NSC-26271). Cancer Treatment Reports, 60, 477-482.

[8] Park, D., Jeon, J.H., Shin, S., Joo, S.S., Kang, D.H., Moon, S.H., Jang, M.J., Cho, Y.M., Kim, J.W., Ji, H.J., Ahn, B., Oh, K.W. and Kim, Y.B. (2009) Green Tea Extract Increases Cyclophosphamide-Induced Teratogenesis by Modulating the Expression of Cytochrome P-450 mRNA. Reproductive Toxicology, 27, 79-84. http://dx.doi.org/10.1016/j.reprotox.2008.11.058

[9] Torchinsky, A., Savion, S., Gorivodsky, M., Shepshelovich, J., Zaslavsky, Z., Fein, A. and Toder, V. (1995) Cyclophosphamide-Induced Teratogenesis in ICR Mice: The Role of Apoptosis. Teratogenesis, Carcinogenesis and Mutagenesis, 15, 179-190. http://dx.doi.org/10.1002/tcm.1770150404

[10] Bailey, M.M., Sawyer, R.D., Behling, J.E., Boohaker, J.G., Hicks, J.G., O’Donnell, M.A., Stringer, K.R., Rasco, J.F. and Hood, R.D. (2005) Prior Exposure to Indole-3-Carbinol Decreases the Incidence of Specific CyclophosphamideInduced Developmental Defects in Mice. Birth Defects Research: Part B Developmental and Reproductive Toxicology, 74, 261-267. http://dx.doi.org/10.1002/bdrb.20046

[11] Umemura, K., Itoh, T., Hamada, N., Fujita, Y., Akao, Y., Nozawa, Y., Matsuura, N., Iinuma, M. and Ito, M. (2008) Preconditioning by Sesquiterpene Lactone Enhances $\mathrm{H}_{2} \mathrm{O}_{2}$-Induced Nrf2/ARE Activation. Biochemical and Biophysical Research Communications, 368, 948-954. http://dx.doi.org/10.1016/j.bbrc.2008.02.018

[12] Araújo Júnior, F.A., Braz, M.N. and Rocha Neto, O.G., Costa, F.D. and Brito, M.V.H. (2005) Efeito do óleo de copaíba nas aminotransferases de ratos submetidos à isquemia e reperfusão hepática come sem pré-condicionamento isquêmico. Acta Cirurgica Brasileira, 20, 93-99. http://dx.doi.org/10.1590/S0102-86502005000100013

[13] Salewski, E. (1964) Färbemethoden Zum Makroskopischen Nachweis von Implantationsstellen am Uterus der Ratte. Naunyn-Schmiedeberg's Archivesof Pharmacology, 247, 367. http://dx.doi.org/10.1007/BF02308461

[14] Calderon, I.M.P., Rudge, M.V.C., Brasil, M.A.M. and Henry, M.A.C.A. (1992) Diabete e gravidez experimental em ratas: 1. Indução do diabete, obtenção e evolução da prenhez. Acta Cirúrgica Brasileira, 7, 142-146.

[15] Staples, R.E. and Schnell, V.L. (1964) Refinements in Rapid Clearing Technic in the KOH-Alizarin Red S Method for Fetal Bone. Stain Technology, 39, 61-63.

[16] Barrow, M.V. and Taylor, W.J. (1969) A Rapid Method for Detecting Malformations in Rat Fetuses. Journal of Morphology, 127, 291-306. http://dx.doi.org/10.1002/jmor.1051270303

[17] Wilson, J.G. (1965) Methods for Administering Agents and Detecting Malformations in Experimental Animals. In: Wilson, J.G. and Warkany, J., Eds., Teratology: Principals and Techniques, University of Chicago Press, Chicago, 262-277.

[18] Taylor, P. (1986) Practical Teratology. Academic Press, London.

[19] Desesso, J.M., Scialli, A.R. and Goeringer, G.C. (1994) D-Mannitol, a Specific Hydroxyl Free Radical Scavenger, Reduces the Developmental Toxicity of Hydroxyurea in Rabbits. Teratology, 49, 248-259. http://dx.doi.org/10.1002/tera.1420490404

[20] Haque, R., Bin-Hafeez, B., Parvez, S., Pandey, S., Sayeed, I., Ali, M. and Raisuddin, S. (2003) Aqueous Extract of Walnut (Juglans regia L.) Protects Mice against Cyclophosphamide-Induced Biochemical Toxicity. Human \& Experimental Toxicology, 22, 473-480. http://dx.doi.org/10.1191/0960327103ht388oa

[21] Veiga Junior, V.F., Rosas, E.C., Carvalho, M.V., Henriques, M.G. and Pinto, A.C. (2007) Chemical Composition and Anti-Inflammatory Activity of Copaiba Oils from Copaifera cearensis Huber ex Ducke, Copaifera reticulata Ducke and Copaifera multijuga Hayne-A Comparative Study. Journal of Ethnopharmacology, 112, 248-254.

http://dx.doi.org/10.1016/j.jep.2007.03.005 
[22] Kim, J.Y., Oh, T.H., Kim, B.J., Kim, S.S., Lee, N.H. and Hyun, C.G. (2008) Chemical Composition and AntiInflammatory Effects of Essential Oil from Farfugium japonicum Flower. Journal of Oleo Sciences, 57, 623-628. http://dx.doi.org/10.5650/jos.57.623

[23] Chaieb, K., Zmantar, T., Ksouri, R., Hajlaoui, H., Mahdouani, K., Abdelly, C. and Bakhrouf, A. (2007) Antioxidant Properties of the Essential Oil of Eugenia Caryophyllata and Its Antifungal Activity against a Large Number of Clinical Candida Species. Mycoses, 50, 403-406. http://dx.doi.org/10.1111/j.1439-0507.2007.01391.X

[24] Lee, S.R., Kim, M.R., Yon, J.M., Baek, I.J., Park, C.G., Lee, B.J., Yun, Y.W. and Nam, S.Y. (2009) Black Ginseng Inhibits Ethanol-Induced Teratogenesis in Cultured Mouse Embryos through Its Effects on Antioxidant Activity. Toxicology in Vitro, 23, 47-52. http://dx.doi.org/10.1016/j.tiv.2008.10.001

[25] Costa-Lotufo, L.V., Cunha, G.M.A., Farias, P.A.M., Viana, G.S.B., Cunha, K.M.A., Pessoa, C., Moraes, M.O., Silveira, E.R., Gramosa, N.V. and Rao, V.S.N. (2002) The Cytotoxic and Embryotoxic Effects of Kaurenoic Acid, a Diterpene Isolated from Copaifera langsdorffii Oleo-Resin. Toxicon, 40, 1231-1234. http://dx.doi.org/10.1016/S0041-0101(02)00128-9

[26] Carvalho, J.C., Cascon, V., Possebon, L.S., Morimoto, M.S., Cardoso, L.G., Kaplan, M.A. and Gilbert, B. (2005) Topical Antiinflammatory and Analgesic Activities of Copaifera duckei Dwyer. Phytotherapy Research, 19, 946-950. http://dx.doi.org/10.1002/ptr.1762

[27] Tincusi, B.M., Jiménez, I.A., Bazzocchi, I.L., Moujir, L.M., Mamani, Z.A., Barroso, J.P., Ravelo, A.G. and Hernández, B.V. (2002) Antimicrobial Terpenoids from the Oleoresin of the Peruvian Medicinal Plant Copaifera paupera. Planta Medica, 68, 808-812. http://dx.doi.org/10.1055/s-2002-34399

[28] Gomes, N.M., Rezende, C.M., Fontes, S.P., Matheus, M.E. and Fernandes, P.D. (2007) Antinociceptive Activity of Amazonian Copaiba Oils. Journal of Ethnopharmacology, 109, 486-492. http://dx.doi.org/10.1016/j.jep.2006.08.018

[29] Santos, A.O., Ueda-Nakamura, T., Dias Filho, B.P., Veiga Junior, V.F., Pinto, A.C. and Nakamura, C.V. (2008) Antimicrobial Activity of Brazilian Copaiba Oils Obtained from Different Species of the Copaifera genus. Memórias do Instituto Oswaldo Cruz, 103, 277-281.

[30] Lima Silva, J.J., Guimarães, S.B., da Silveira, E.R., de Vasconcelos, P.R., Lima, G.G., Torres, S.M. and de Vasconcelos, R.C. (2009) Effects of Copaifera langsdorffii Desf. on Ischemia-Reperfusion of Randomized Skin Flaps in Rats. Aesthetic Plastic Surgery, 33, 104-109. http://dx.doi.org/10.1007/s00266-008-9263-2

[31] Sachetti, C.G., de Carvalho, R.R., Paumgartten, F.J.R., Lameira, O.A. and Caldas, E.D. (2011) Developmental Toxicity of Copaiba Tree (Copaifera reticulata Ducke, Fabaceae) Oleoresin in Rat. Food and Chemical Toxicology, 49, 1080-1085. http://dx.doi.org/10.1016/j.fct.2011.01.015

[32] Jang, D.S., Min, H.Y., Kim, M.S., Han, A.R., Windono, T., Jeohn, G.H., Kang, S.S., Lee, S.K. and Seo, E.K. (2005) Humulene Derivatives from Zingiber zerumbet with the Inhibitory Effects on Lipopolysaccharide-Induced Nitric Oxide Production. Chemical and Pharmaceutical Bulletin, 53, 829-831. http://dx.doi.org/10.1248/cpb.53.829

[33] Farag, R.S., Shalaby, A.S., El-Baroty, G.A., Ibrahim, N.A., Ali, M.A. and Hassan, E.M. (2004) Chemical and Biological Evaluation of the Essential Oils of Different Melaleuca Species. Phytotherapy Research, 18, 30-35. http://dx.doi.org/10.1002/ptr.1348

[34] Jirovetz, L., Buchbauer, G., Stoilova, I., Stoyanova, A., Krastanov, A. and Schmidt, E. (2006) Chemical Composition and Antioxidant Properties of Clover Leaf Essential Oil. Journal of Agricultural and Food Chemistry, 54, 6303-6307. http://dx.doi.org/10.1021/jf060608c

[35] Mimica-Dukic, N., Bozin, B., Sokovic, M. and Simin, N. (2004) Antimicrobial and Antioxidant Activities of Melissa officinalis L. (Lamiaceae) Essential Oil. Journal of Agricultural and Food Chemistry, 52, 2485-2489. http://dx.doi.org/10.1021/jf030698a

[36] Hosako, H., Little, S.A., Barrier, M. and Mirkes, P.E. (2007) Teratogen-Induced Activation of p53 in Early Postimplantation Mouse Embryos. Toxicological Sciences, 95, 257-269. http://dx.doi.org/10.1093/toxsci/kfl143

[37] Slott, V.L. and Hales, B.F. (1987) Enhancement of the Embryotoxicity of Acrolein, but Not Phosphoramide Mustard, by Glutathione Depletion in Rat Embryos in Vitro. Biochemical Pharmacology, 36, 2019-2025. http://dx.doi.org/10.1016/0006-2952(87)90503-X

[38] Little, S.A. and Mirkes, P.E. (2002) Teratogen-Induced Activation of Caspase-9 and the Mitochondrial Apoptotic Pathway in Early Postimplantation Mouse Embryos. Toxicology and Applied Pharmacology, 181, 142-151. http://dx.doi.org/10.1006/taap.2002.9414 
Scientific Research Publishing (SCIRP) is one of the largest Open Access journal publishers. It is currently publishing more than 200 open access, online, peer-reviewed journals covering a wide range of academic disciplines. SCIRP serves the worldwide academic communities and contributes to the progress and application of science with its publication.

Other selected journals from SCIRP are listed as below. Submit your manuscript to us via either submit@scirp.org or Online Submission Portal.
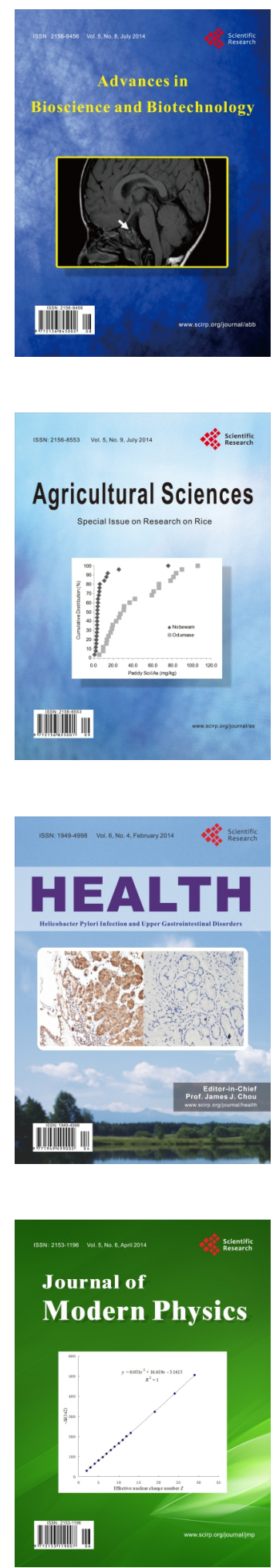
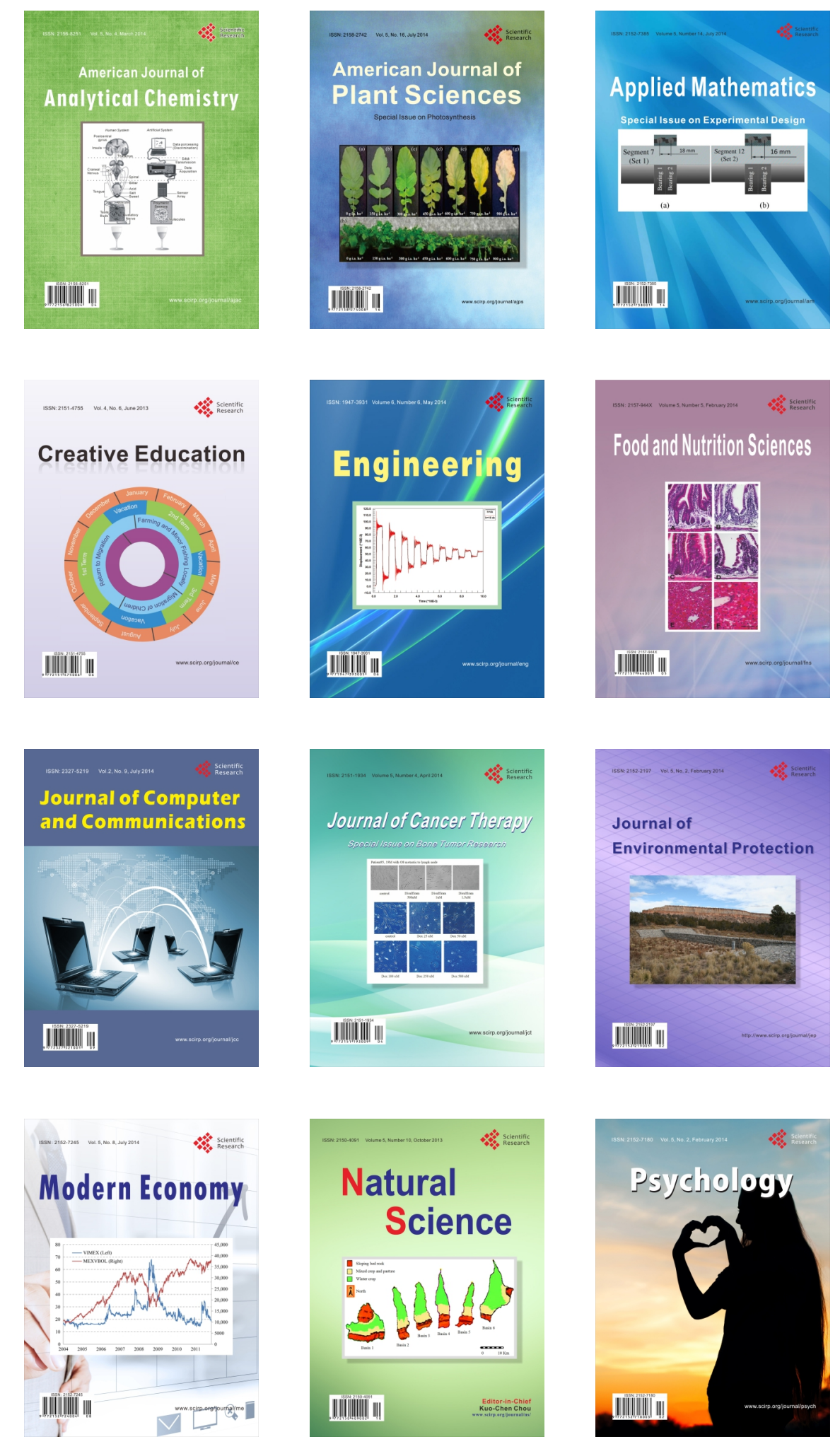